\title{
REVIEW
}

\section{The Evolving Role of Companion Diagnostics for Breast Cancer in an Era of Next-Generation Omics}

\author{
Jason N. Rosenbaum* and Paul Weisman ${ }^{\dagger}$
}

From the Perelman School of Medicine Center for Personalized Diagnostics, * University of Pennsylvania, Philadelphia, Pennsylvania; and the Department of Pathology and Laboratory Medicine, ${ }^{\dagger}$ University of Wisconsin Hospital and Clinics, Madison, Wisconsin

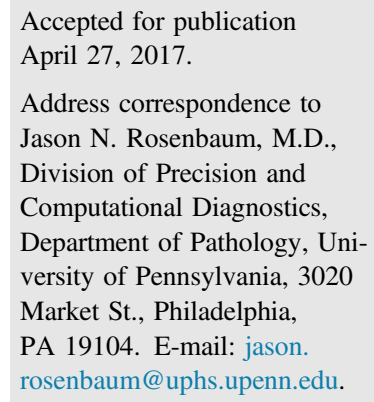

\section{Companion Diagnostics}

As interest has grown in precision medicine, the concept of companion diagnostics has gained increasing purchase among laboratory professionals, clinicians, regulators, and even patients. The United States Food and Drug Administration (FDA) defines an in vitro companion diagnostic device (an IVD companion diagnostic) as a device or test "that provides information that is essential for the safe and effective use of a corresponding therapeutic product" (https://www.fda.gov/ downloads/MedicalDevices/DeviceRegulationandGuidancel GuidanceDocuments/UCM262327.pdf and http://www. fda.gov/ucm/groups/fdagov-public/@fdagov-meddev-gen/ documents/document/ucm510824.pdf, last accessed April 4, 2017). This definition is fairly broad and could in principle be applied to a sphygmomanometer used to prescribe a $\beta$-blocker; in practice, a companion diagnostic has been more properly understood as a test for a specific finding that rules a patient in or out for a specific therapy based on that finding. The specificity is important; a sphygmomanometer detecting a blood pressure above a certain threshold may trigger the use of $\beta$-blockers, but that should not be the only therapy considered.
Conversely, $\beta$-blockers may be prescribed for multiple conditions, only some of which are triggered by a specific blood pressure. Thus, the term companion diagnostic is best understood as a dyad between test and therapy.

Molecular genomic findings often carry the most specific association with a targetable disease mechanism. For this reason, companion diagnostics are most often understood and applied (and indeed, evolved as a concept) in the context of specific molecular genomic findings identifying oncology patients likely to respond to targeted therapy. Indeed, the prototype for the companion diagnostic model would almost certainly be translocation between chromosomes 9 and 22 [the Philadelphia chromosome, $t(9 ; 22)]$ as indication for treatment with imatinib (Gleevec; Novartis, Basel, Switzerland). To date, the current list of FDA-approved IVD companion diagnostics remains almost exclusively based on molecular oncology targets; in breast cancer, most are based on protein detection by immunohistochemistry

Disclosures: None declared.

This article is part of a review series on next-generation breast cancer omics. 
Table 1 IVD Companion Diagnostics in Breast Cancer

\begin{tabular}{|c|c|c|c|c|c|}
\hline Biomarker & Companion diagnostic & Manufacturer & Method & FDA status & Associated therapy \\
\hline \multirow[t]{12}{*}{ Her-2 (ERBB2) } & HercepTest & $\begin{array}{l}\text { Dako (Glostrup Municipality, } \\
\text { Denmark) }\end{array}$ & Overexpression (IHC) & Approved & $\begin{array}{l}\text { Trastuzumab } \\
\text { Pertuzumab } \\
\text { Ado-trastuzumab } \\
\text { emtansine }\end{array}$ \\
\hline & HER-2 IQFISH pharmDx & Dako & Amplification (FISH) & Approved & Trastuzumab \\
\hline & & & & & $\begin{array}{l}\text { Pertuzumab } \\
\text { emtansine }\end{array}$ \\
\hline & Inform Her-2/Neu & $\begin{array}{l}\text { Ventana Medical Systems, } \\
\text { Inc. (Oro Valley, AZ) }\end{array}$ & Amplification (FISH) & Approved & Trastuzumab \\
\hline & PathVysion Her-2 & $\begin{array}{l}\text { Abbott Laboratories (Lake } \\
\text { Bluff, IL) }\end{array}$ & Amplification (FISH) & Approved & Trastuzumab \\
\hline & Pathway anti-Her-2/Neu & $\begin{array}{l}\text { Ventana Medical Systems, } \\
\text { Inc. }\end{array}$ & Overexpression (IHC) & Approved & Trastuzumab \\
\hline & InSite Her-2/Neu & Biogenex (Fremont, CA) & Overexpression (IHC) & Approved & Trastuzumab \\
\hline & SPOT-LIGHT Her-2 CISH & $\begin{array}{l}\text { Life Technologies } \\
\quad \text { (Invitrogen; Carlsbad, CA) }\end{array}$ & Amplification (CISH) & Approved & Trastuzumab \\
\hline & Bond Oracle Her-2 IHC & $\begin{array}{l}\text { Leica Biosystems (Wetzlar, } \\
\text { Germany) }\end{array}$ & Overexpression (IHC) & Approved & Trastuzumab \\
\hline & HER-2 CISH pharmDx & Dako & Amplification (CISH) & Approved & Trastuzumab \\
\hline & Inform Her-2 Dual ISH & $\begin{array}{l}\text { Ventana Medical Systems, } \\
\text { Inc. }\end{array}$ & $\begin{array}{l}\text { Amplification } \\
\text { (2-color CISH) }\end{array}$ & Approved & Trastuzumab \\
\hline & HERmark & $\begin{array}{l}\text { Monogram Biosciences } \\
\quad \text { (South San Francisco, CA) }\end{array}$ & $\begin{array}{l}\text { Overexpression } \\
\text { (protein } \\
\text { quantification) }\end{array}$ & $\begin{array}{l}\text { NA (CLIA } \\
\text { validated) }\end{array}$ & NA \\
\hline \multirow[t]{9}{*}{$B R C A 1 / 2$} & FoundationFocus $C D \times B R C A$ & $\begin{array}{l}\text { Foundation Medicine, Inc. } \\
\text { (Cambridge, MA) }\end{array}$ & $\begin{array}{l}\text { Massively parallel } \\
\text { sequencing (MPS) }\end{array}$ & Approved* & Rucaparib \\
\hline & BRCAnalysis CDx & $\begin{array}{l}\text { Myriad Genetics (Salt Lake } \\
\text { City, UT) }\end{array}$ & $\begin{array}{r}\text { PCR \& Sanger } \\
\text { sequencing }\end{array}$ & Approved* & Rucaparib \\
\hline & & & & & Olaparib \\
\hline & & & & & Talazoparib \\
\hline & & & & & Niraparib \\
\hline & & & & & Veliparib \\
\hline & myChoice HRD & Myriad Genetics & Mutational signature & Investigational & Talazoparib \\
\hline & & & & & Niraparib \\
\hline & & & & & Veliparib \\
\hline \multirow[t]{4}{*}{ PD-L1 } & PD-L1 IHC 22 C3 pharmDx & Dako & Expression (IHC) & Approved* & Pembrolizumab \\
\hline & PD-L1 IHC 28-8 pharmDx & Dako & Expression (IHC) & Approved $^{\dagger}$ & Nivolumab \\
\hline & PD-L1 (SP142) assay & Roche (Basel, Switzerland) & Expression (IHC) & Approved $^{\dagger}$ & Atezolizumab \\
\hline & PD-L1 (SP263) assay & Roche & Expression (IHC) & Approved $^{\dagger}$ & Durvalumab \\
\hline PIK3CA & cobas 4800 PIK3CA assay & Roche & $\begin{array}{l}\text { Mutation } \\
\quad \text { (sequencing) }\end{array}$ & Investigational & Alpelesib (BYL719) \\
\hline
\end{tabular}

The table is meant to be representative, not exhaustive.

*Approved in another cancer type.

${ }^{\dagger}$ Approved as a complementary diagnostic, rather than a companion diagnostic.

CDx, companion diagnostic; CISH, chromogenic in situ hybridization; CLIA, Clinical Laboratory Improvement Amendments; FISH, fluorescent in situ hybridization; HRD, homologous recombination deficiency; IHC, immunohistochemistry; NA, not applicable; PD-L1, programed cell death 1 ligand; PIK3CA, phosphatidylinositol-4,5-bisphosphate 3-kinase catalytic subunit $\alpha$.

(IHC) (Table 1 and Figure 1) (https://www.fda.gov/ MedicalDevices/ProductsandMedicalProcedures/InVitro Diagnostics/ucm301431.htm, last accessed April 4, 2017).

The evolution of biomarkers used to stratify and treat breast cancer illustrates the history of companion diagnostics, and provides a lens through which to examine current and future challenges. Although not all biomarkers considered below are IVD companion diagnostics according to the FDA definition, many function in a similar manner, and they all provide biological, clinical, and historical context and are therefore useful to consider. Table 1 provides a comparison of several existing and investigational IVD companion diagnostic assays for breast cancer, and Figure 1 places the most commonly used assays in the context of their clinical application. 
A

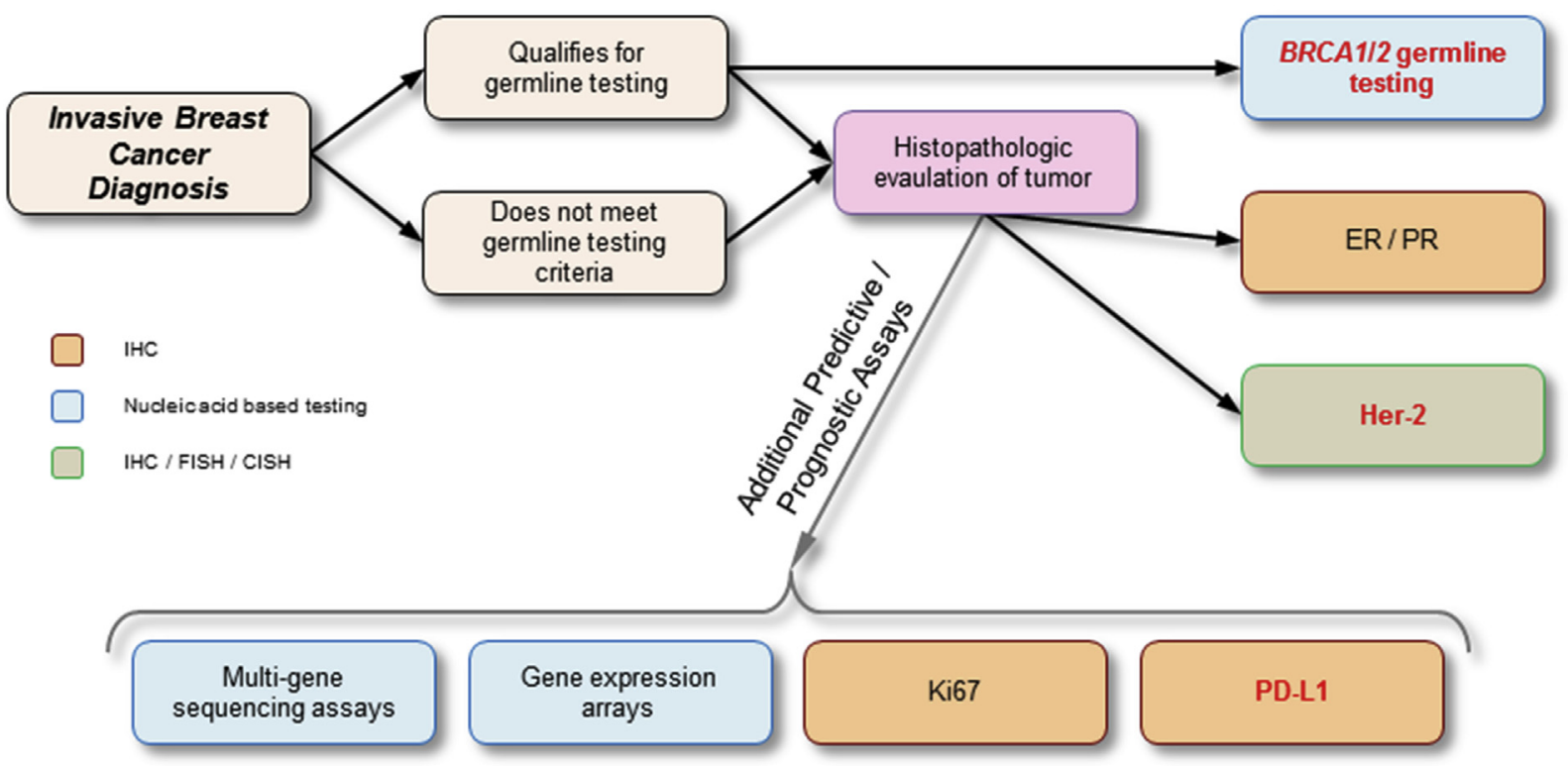

B

\begin{tabular}{|c|c|c|c|c|c|c|}
\hline $\begin{array}{l}\text { Expression } \\
\text { Pattern }\end{array}$ & $\begin{array}{l}\text { Molecular } \\
\text { Subtype }\end{array}$ & Ki67 & Grade & Prognosis & $\begin{array}{l}\text { Standard } \\
\text { Therapy }\end{array}$ & $\begin{array}{l}\text { Selected Genomic } \\
\text { Alterations }\end{array}$ \\
\hline ER/PR + & Luminal A & Low & Low & Favorable & Endocrine & PIK3CA variants \\
\hline $\begin{array}{c}\mathrm{ER} / \mathrm{PR}+\& \\
\mathrm{Her} 2+\end{array}$ & Luminal B & & Intermediate & $\Delta$ & $\begin{array}{l}\text { Endocrine / } \\
\text { Her2 targeted }\end{array}$ & $\begin{array}{c}\text { ERBB2 } \\
\text { amplification }\end{array}$ \\
\hline Her2 + & Her2 + & & & & Her2 targeted & \\
\hline $\begin{array}{c}\text { Triple } \\
\text { Negative }\end{array}$ & $\begin{array}{l}\text { Triple } \\
\text { Negative }\end{array}$ & High & $\begin{array}{c}\text { High } \\
\text { (Grade III) }\end{array}$ & Poor & Chemotherapy & TP53 variants \\
\hline
\end{tabular}

Figure 1 Evaluation of invasive breast cancer includes companion diagnostic (CDx) assays. A: A schematic representation of the most commonly applied diagnostic assays for invasive breast cancer illustrates the role for $C D x$ assays. Tests that currently include a CDx component are highlighted in bold red text.

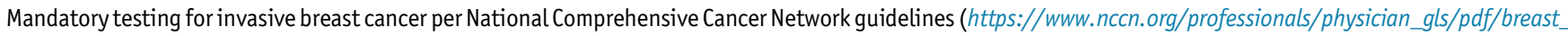
blocks.pdf, last accessed April 4, 2017). Before or concurrent with histopathologic assessment of the tumor, evaluation of personal and family history may necessitate germline testing for hereditary BRCA1 or BRCA2 variants (https://www.tri-kobe.org/hccn/guideline/gynecological/english/genetic_familial.pdf, last accessed April 4, 2017). Currently, assays for the BRCA genes are approved as CDx for poly-ADP ribose polymerase inhibitors only in the context of ovarian cancer (Table 1). Importantly, germline testing should always be accompanied by appropriate counseling and should not be performed solely on tumor tissue. Narrowly targeted testing for the confirmation of a known familial variant may differ in methodology from assays that are agnostic regarding the presence of a specific variant, such as the CDx assays listed in Table 1. Regardless of whether germline testing is performed, all invasive breast carcinoma is evaluated for estrogen receptor (ER) and progesterone receptor (PR) expression by immunohistochemistry (IHC). Overexpression of Her-2/Neu protein may also be evaluated by IHC or may be inferred from the amplification of the ERBB2 gene, detected by fluorescent or chromogenic in situ hybridization (FISH or CISH). Additional testing (not mandatory by current guidelines) is often applied for predictive (therapeutic) or prognostic purposes. IHC for Ki-67 may be applied concurrently with IHC for other markers, offers a global assessment of the proliferative nature of the cancer, but standardization and reproducibility are of concern. If immune-checkpoint inhibitors are a therapeutic consideration, IHC assays for programmed cell death 1 (PD-L1) expression may also be applied if there is sufficient tissue. Only one IHC assay is approved as a CDx in non-small cell lung cancer, with others as complementary diagnostics or in development. Nucleic acid-based tests (gene expression arrays and multigene sequencing panels) have different tissue processing, equipment, analytical, and interpretive requirements, which can extend turn-around time. Moreover, these assays are often sent to external laboratories. B: Gene expression arrays can categorize breast cancer by molecular subtype and may inform prognosis and therapeutic response (particularly to chemotherapy). The reliability and equivalence between different gene expression assays are not well established. Multigene sequencing assays (usually by massively parallel sequencing) vary considerably in target coverage and detectable genomic alterations (eg, whether specific genes are included, copy number changes are detectable, and the maximum size of detectable insertions/deletions), but when properly designed they can produce predictive and prognostic data. Such assays are currently most helpful in the context of disease progression, unexplained therapeutic resistance, and candidacy for clinical trials, but they can also provide information otherwise arrived at through CDx assays (eg, deleterious BRCA1/2 gene variants and ERBB2 amplification). The data from these assays are used, along with clinical data and pathologic staging, to stratify patients for treatment. 


\section{ER, PR, and Her-2}

Estrogen receptor (ER), progesterone receptor (PR), and Her-2 are the protein products of the ESRI, PGR, and $E R B B 2$ genes, respectively. The use of IHC to detect expression of ER and/or PR predates the formal adoption of the IVD companion diagnostics model by decades; however, expression of either ER or PR stratifies patients by their presumptive response to therapy targeted at the estrogen-response mechanism. ${ }^{1-5}$ In the case of these hormone receptors, the diagnostic finding is not paired to a single drug (or even class of drugs) in a stereotyped manner. Instead, expression of either hormone receptor corresponds with several treatments and classes of drugs that converge on the same molecular pathway. ${ }^{6}$ Thus, ER/PR testing functions similarly to FDA-approved IVD companion diagnostics. Indeed, some of the challenges posed by ER/PR testing informed later companion diagnostic development, providing contrast and context to more conventional companion diagnostics.

Evaluation of ER and PR began in the 1970s to assess potential response to antiestrogen therapy, including aromatase inhibitors, selective estrogen modulators, and oophorectomy. ER and PR are hormone receptors that bind their respective ligands and translocate to the nucleus, where they bind DNA and activate transcription of downstream targets. The transcriptional targets of activated ER drive a number of cellular processes related to cancer, including proliferation and differentiation. Approximately $70 \%$ of patients with breast carcinoma have tumors that express ER and/or PR, and therapy directed at the estrogen pathway, which acts to remove or antagonize the stimulatory effect of estrogen, significantly reduces the recurrence and mortality rates in these patients. ${ }^{7,8}$ Given the prevalence of breast carcinoma (there are an estimated 252,710 new cases of invasive breast cancer per year), ER and PR testing by IHC has improved clinical outcomes for a substantial number of breast cancer patients (https://www.cancer.org/research/ cancer-facts-statistics/all-cancer-facts-figures/cancer-factsfigures-2017.html, last accessed April 4, 2017). Endocrine therapy to block the ER pathway is highly effective, but its usefulness is limited by common intrinsic and acquired resistance mechanisms, including deregulation of various components, alterations in cell cycle and cell survival signaling molecules, and activation of escape pathways that can provide tumors with alternative proliferative and survival stimuli. Among these, increased expression or signaling of growth factor receptor pathways, especially the epidermal growth factor receptor/Her-2 pathway, is associated with both experimental and clinical endocrine therapy resistance. New treatment combinations targeting ER and growth factor receptor signaling which block the crosstalk between these pathways and eliminate escape routes have proved highly effective in preclinical models. Results of recent clinical studies, although partly supporting this approach, also highlight the need to better identify $a$ priori the appropriate patients whose tumors are most likely to benefit from specific cotargeting strategies.

Although expression of ER and PR is an important marker for breast cancer, genetic changes driving tumor behavior initially remained opaque. That changed with a deepening understanding of the molecular mechanisms driving cancer. In the late 1980s, amplification of the Her-2/ Neu genomic locus was identified as an independent prognostic factor in breast cancer. ${ }^{9}$ Her-2/Neu (alias Her-2 or $E R B B 2$ ) encodes a receptor tyrosine kinase member of the epidermal growth factor receptor family. Excess kinase drives downstream oncogenic pathways, which include a number of other known oncogenes. Because the Her-2 protein product is a receptor kinase, it provided an opportunity to develop a comparatively specific, targeted therapy directed at a specific genomic alteration. In the early 1990s, trastuzumab (Herceptin; Roche, Basel, Switzerland) was approved by the FDA along with one of the earliest true IVD companion diagnostics, the immunocytochemical assay HercepTest, designed to detect Her-2 protein in formalin-fixed, paraffin-embedded tissue. ${ }^{10-12}$

Conventional ER, PR, and Her-2 analyses, including the approved companion diagnostics, rely on IHC or in situ hybridization (ISH) techniques, which require visualization of the biomarker in tissue. These techniques and their interpretation carry with them some variability. In the early days of testing, a lack of reproducibility between laboratories led to clinical uncertainty and divergent outcomes. Ultimately, this uncertainty drove considerable effort to standardize processes and techniques. Much of the inconsistency was attributed to variability in specimen handling before analysis, primarily the amount of time between surgical removal of the tissue and fixation (ischemic time), and the amount of time the tissue spent in formalin fixative (fixation time). ${ }^{13-17}$ Analytic variability arose from differences in properties of different specific IHC antibodies ${ }^{18}$ and inconsistent interpretation of the IHC signal, which even under precisely controlled conditions varies in both staining intensity and the proportion of cells stained. ${ }^{7,19}$ Recognition of the breadth and scope of confounding factors led to extensive efforts to determine appropriate standards and apply them to practice guidelines. ${ }^{6,20-24}$ Recent work has further suggested that not all IHC antibodies are equivalent in their prognostic or predictive ability, because Her-2 undergoes cleavage into intracellular and extracellular domains as part of its biological mechanism, suggesting that antibodies directed at extracellular epitopes may better predict response to therapy directly targeting Her-2. ${ }^{25}$ The struggle to standardize assessment of ER/PR and Her-2 directly has affected the development and adoption of later biomarker assays and more generally influenced the overall FDA strategy of IVD companion diagnostics.

A number of other assays using other techniques have since come to market as alternatives to HercepTest, making use of alternative IHC antibodies, fluorescence ISH, chromogenic ISH, or proprietary protein quantification methods 
(Table 1). However, the clinical utility of the growing number of alternative Her-2 assays has yet to be borne out in practice. For instance, the use of alternative Her-2 fluorescence ISH probes in cases previously scored as equivocal with the use of standard fluorescence ISH probes may result in the re-classification of up to $40 \%$ of such cases as amplified. Nevertheless, the lack of prospective clinical trials to evaluate the response of these patients to targeted therapy renders these results clinically ambiguous. ${ }^{26}$

Not all variability in therapeutic response is attributable to different assay technologies or their practical application; biology maintains inherent variability as well. Although most tumors expressing ER and/or PR respond to estrogenmodulating therapies, a significant portion do not. Some of this discrepancy can be explained by the intratumoral heterogeneity. Breast cancer, as with most malignancies, evolves over time, accruing new genomic changes. This process can generate intratumoral subclones or distant metastases with distinct genomic profiles (spatial heterogeneity). ${ }^{27,28}$ Differences among subclones can lead to different responses to therapy, including the development of resistance (temporal heterogeneity). Indeed, heterogeneity in Her-2 expression is an independent predictor of poorer outcomes in breast carcinoma. ${ }^{29}$ IHC and ISH-although capable of identifying heterogeneity of expression - cannot necessarily identify the acquisition of resistance mutations.

Variants in ESRl may alter the responsiveness of the receptor to antiestrogen therapy without changing the expression of the protein. ${ }^{30-33}$ ERBB2 can also acquire therapeutic resistance via a number of genetic mechanisms, many of which are undetectable by current companion diagnostics. ${ }^{34}$ Moreover, the mRNA transcript is subject to alternative splicing, which can also disrupt ER function without altering ER IHC detection. ${ }^{35}$ In contrast to the resistance variants in $E S R 1$, activating mutations have been described in ERBB2. ${ }^{36-38}$ Some of these variants respond to anti-Her-2 therapy, even in the absence of Her-2 overexpression. In the presence of resistance or loss-of-function alterations (because of mutations or alternative splicing) standard IHC or ISH testing will overestimate patients who will respond to targeted therapy, whereas in the presence of driver mutations the same testing will fail to identify patients who may benefit from such therapy. Thus, the more additional information available regarding specific cellular and genetic properties of a tumor, the more precisely therapy can be tailored. The relevant data, though, are not provided by existing FDA-approved IVD companion diagnostic assays.

\section{Sequencing, Clinical Genomics, and Future Companion Diagnostics}

Despite the broad use of ER, PR, and Her-2 as biomarkers in treatment, these genes are not among the most frequently mutated in breast cancer. A host of studies mining large data sets have identified recurrent molecular alterations in breast cancer, including potential driver mutations, molecular signatures, and other diagnostic features, ${ }^{27,28,39-46}$ any of which may potentially lead to a targeted therapy that could be paired with an IVD companion diagnostic. Not every potential therapeutic target easily lends itself to a straightforward diagnostic test, however.

Two of the most prominent genes in breast cancer pathology-the homologous DNA-repair genes breast cancer 1 (BRCA1) and breast cancer 2 (BRCA2) - are best known for harboring germline variants associated with hereditary breast and ovarian cancer syndrome, ${ }^{47}$ although somatic variants occur as well. ${ }^{48}$ Rucaparib, a poly-ADP ribose polymerase inhibitor, has recently been approved for use in ovarian cancer with a PCR/Sanger sequencing-based companion diagnostic (BRACAnalysis CDX; Myriad Genetic Laboratories, Salt Lake City, UT),${ }^{49-53}$ and a massively parallel sequencing (MPS, alias next-generation sequencing) assay (FoundationFocus CDxBRCA; Foundation Medicine, Inc., Cambridge, MA) (Table 1) (https://www. fda.gov/MedicalDevices/ProductsandMedicalProcedures/ InVitroDiagnostics/ucm301431.htm, last accessed April 4, 2017). Notably, Myriad Genetic Laboratories also offers an alternative diagnostic product identifying the mutational signature of homologous repair deficiency (myChoice HRD). Although many IVD companion diagnostics directly identify the target of therapy, the identification of a mutational signature for $B R C A 1 / 2$ deficiency carries some advantages. The BRCA1 and BRCA2 genes are large and subject to a number of different kinds of alterations, not all of which are reliably identified or interpreted from direct sequencing (eg, large deletions and noncanonical splice-site variants). Perhaps more importantly, homologous repair deficiency itself is agnostic regarding the specific deficient gene and therefore indicates dysfunction in any gene in the homologous repair complex, which includes multiple genes and interacts with a number of other pathways. Accordingly, assays evaluating the functional status of the homologous repair complex, whether directly assessing its functional capacity $^{54}$ or identifying the telltale mutational signature resulting from its dysfunction, ${ }^{46,55}$ may prove to be more inclusive of rare (or even undescribed) drivers of cancer, potentially identifying more patients who might respond to targeted therapy.

BRCA1 and BRCA2 are not unique in interacting as components of larger functional complexes or networks. PIK3CA, the most commonly mutated gene in breast cancer, ${ }^{28}$ encodes the catalytic subunit of the phosphoinositol-3 kinase (PI3K) complex, an upstream component of a multiprotein pathway [PI3K/mechanistic target of rapamycin (mTOR)/AKT pathway], which itself interacts with a number of other cellular pathways. PIK3CA harbors several variant hotspots (eg, variants at amino acids H1047 and Q546), which drive constitutive activity of the kinase complex. Targeted therapies specific to PIK3CA-mutated cancer, including breast cancer, are seeing preliminary 
success in preclinical and clinical trials, ${ }^{56,57}$ and a research use only assay for PIK3CA variants is available from Roche on the cobas 4800 platform (FDA-approved as a platform in other contexts, such as detection of $E G F R$ variants in lung cancer). Other investigational therapies, though, target the PI3K pathway less specifically, ${ }^{58}$ such that patients harboring variants in other pathway components, including PIK3R1, AKT genes, or PTEN (Figure 2), might benefit from treatment. Resistance variants may also develop during therapy anywhere in the pathway. Design of IVD companion diagnostic assays addressing even a majority of relevant genomic alterations to the PI3K pathway may prove challenging. To compound the biological complexity, variants in $P I K 3 C A$ specifically modify prognosis in ER-positive and Her-2-positive breast cancer, independent of PIK3CA as a direct therapeutic target. ${ }^{28,59}$ Multiparametric assays, including genomic analysis, proteomic analysis, and expression arrays, could be used to detect relevant genomic variants in multiple genes and direct anti-PI3K therapy, but none of these types of assays are easily paired with a single therapy or class of therapies.

Variants in the tumor protein p53 (TP53) gene are also common across cancer, including breast cancer. ${ }^{28}$ TP53 encodes a protein that regulates multiple pathways in opposing oncogenesis, including detection of DNA damage and activation of repair mechanisms, cell-cycle arrest, apoptotic activation, and inhibition of angiogenesis, among others. The p53 protein is normally viewed as a tumor suppressor, with loss-of-function variants predominating; however, oncomorphic single-nucleotide variants at hotspot codons are also described. ${ }^{60}$ Like PIK3CA, p53 interacts with a network of other proteins (Figure 2); therefore, it carries some of the same difficulties in developing any effective companion diagnostic for a therapy directed specifically at p53 dysfunction. With regard to targeted therapy, the most notable direct protein interaction of p53 is with mouse double minute homolog 2 (MDM2), which binds p53, maintaining a quiescent state. In the presence of functional p53, MDM2 antagonists (such as idasanutlin, currently in clinical trials) release p53 to perform its normal tumor suppressive functions. ${ }^{61-64}$ In a significant proportion of breast cancer, MDM2 is amplified or TP53 is mutated (usually in a mutually exclusive manner), suggesting that anti-MDM2 therapy may be efficacious in the appropriate genomic context. It is straightforward to imagine the development and implementation of a companion diagnostic for MDM2 amplification; however, successful treatment with MDM2 inhibitors does require the presence of at least one functional TP53 allele. TP53 is one of the most mutable genes in cancer, both before and during treatment. Combinatorial detection of MDM2 amplification (by ISH or IHC) with p53 expression (by IHC) has potential as a diagnostic strategy, but it cannot account for oncomorphic variants in p53 without additional testing.

Loss of inhibition of the cell cycle is a common finding across breast cancer, although the specific mechanism can vary (Figure 2). Drivers of the cell cycle can be activated or amplified [eg, cyclin D1 (CCNDI) or cyclin-dependent kinase-4 (CDK4)]. Alternatively, cell-cycle repressors may be dysfunctional or lost [eg, cyclin-dependent kinase inhibitors 1B $(C D K N 1 B / \mathrm{p} 27)$ or $2 \mathrm{~A}(C D K N 2 A / \mathrm{p} 16)]$. In these situations, therapy directed at inhibiting CDK4 and/or CDK6 (palbociclib; Novartis) may provide particular benefit. ${ }^{65,66}$ As with BRCA1/BRCA2 testing, designing a companion diagnostic to capture all of the potential targets that might be responsive to anti-CDK4/CDK6 therapy poses challenges, and like MDM2 inhibition, CDK inhibition can be rendered ineffective by loss-of-function variants in an entirely separate, mutable gene, retinoblastoma $1(R B 1)$.

A number of other genomic biomarkers have been identified with enough frequency in breast carcinoma to warrant research and development toward targeted therapeutics with companion diagnostic assays. Amplifications and activating mutations of the fibroblast growth factor $(F G F)$ and fibroblast growth factor receptor $(F G F R)$ gene families collectively occur with enough frequency to make them a viable target to the variety of FGF and FGFR inhibitors under investigation. ${ }^{67}$ Variants in lysine methyl-transferase genes (eg, KMT2C, KMT2D, alias $M L L 3$ and $M L L 2$, respectively) may help specifically target therapy with histone deacetylase inhibitors. ${ }^{68}$ Sequencing-based assays targeted at these genes or indirect assays detecting aberrant methylation profiles can be envisioned in a companion diagnostic strategy for therapy.

\section{Gene Expression Profiling and Ki-67}

As molecular data grow more complex, so too do corresponding clinical diagnostic tests. Gene expression profiling does not meet the strict definition of an IVD companion diagnostic: the results are used to stratify patients for expected response to standard chemotherapeutic regimens but do not necessarily indicate a specific targeted therapy. Operationally, though, gene expression profiles serve a theranostic function, predicting patient response to conventional chemotherapy and, in particular, predicting which patients may be spared the toxicity of chemotherapy. For instance, the TAILORx trial recently confirmed the utility of Oncotype Dx (Genomic Health, Redwood City, CA) in identifying the subset of patients with ER-positive, axillary lymph node-negative invasive carcinoma that may be safely treated with adjuvant endocrine therapy alone. ${ }^{69}$

Expression of Ki-67 protein (the product of the MKI67 gene) is often used in the evaluation of breast carcinoma, but it is not appropriately considered a companion diagnostic. Rather than a targetable biomarker, the $\mathrm{Ki}-67$ antigen is expressed in cells in some phase of the cell cycle. As such, it represents an easily visualizable read-out of a number of different cellular pathways converging on cellular proliferation. Each pathway may contain many components (cyclins, cyclin-dependent kinases, receptor kinases, 


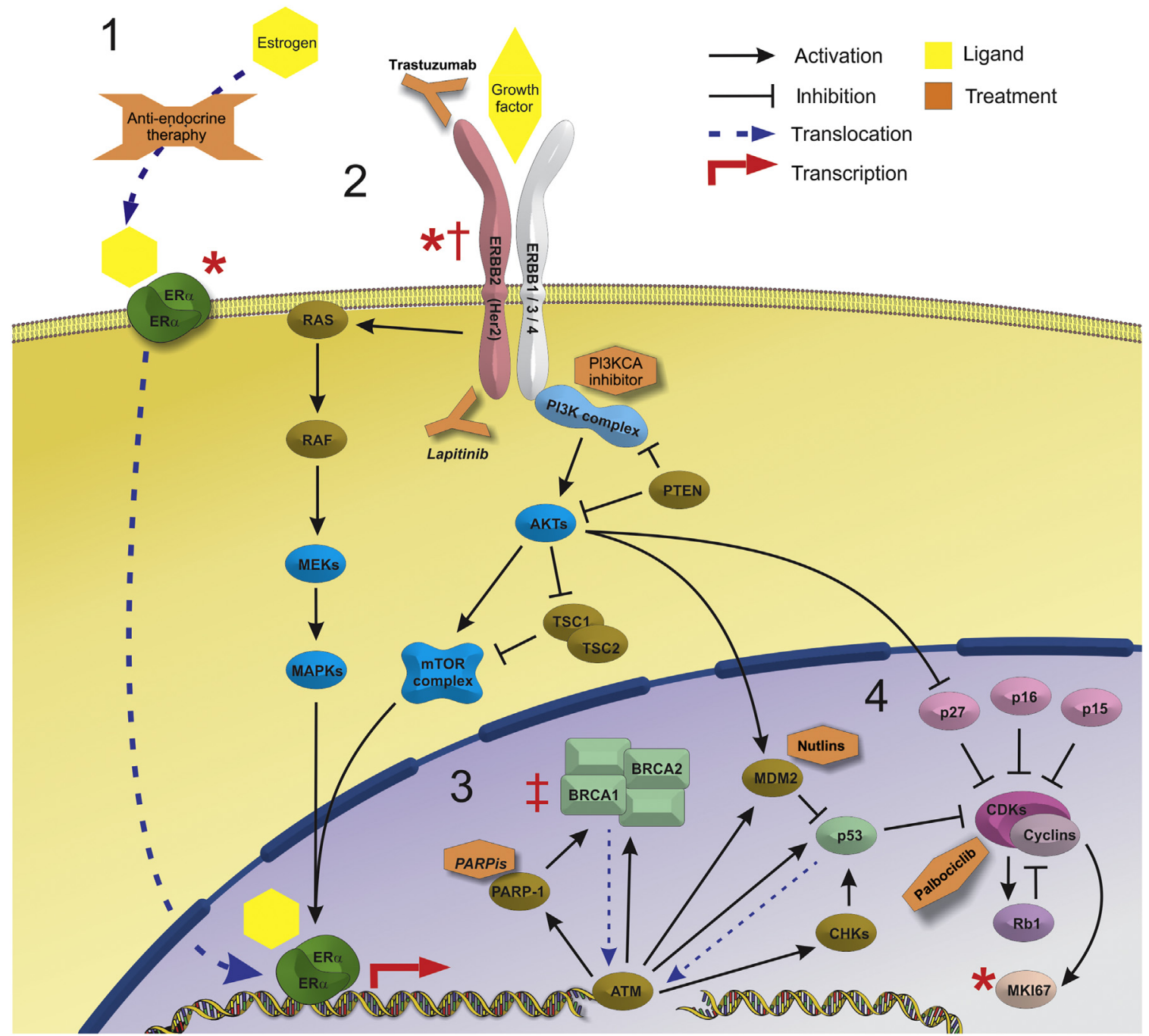

Figure 2 Molecular pathways assessed by companion diagnostics ( $C D x)$ in breast cancer are complex and interconnected. This diagram provides an overview of the molecular pathways driving breast cancer that are targeted by available therapies, therapies available in other cancer types, or therapeutics under clinical trials. Because immune-checkpoint inhibitors act on immune cells, they are not depicted in this diagram. The diagram is not comprehensive-not every pathway, protein, or potential interaction is included. Asterisks indicate markers assessed by immunohistochemistry (IHC); dagger, marker assessed by fluorescent in situ hybridization (FISH)/chromogenic in situ hybridization (CISH); double dagger, marker assessed by nucleic acid sequencing assay. 1: Estrogen binds dimerized membrane-associated estrogen receptor $(E R \alpha)$, resulting in translocation of the complex to the nucleus, where it associates with DNA, transcription factors, and transcription machinery to drive expression of target genes, including those involved in cellular growth and proliferation. ER $\alpha$ also directly activates the cell cycle by antagonizing cell-cycle inhibitors, including p27 (CDKN1B), p15 (CDKN2B), and p16 (CDKN2A). Neoplastic cells expressing ER $\alpha$ and/or progesterone receptor (not shown) are identified by IHC, indicating antiendocrine therapy (eg, selective estrogen receptor modulators, aromatase inhibitors, etc.) may antagonize the neoplastic processes. 2: Separately, growth factor ligand binds a receptor tyrosine kinase heterodimer consisting of Erb-B2 receptor tyrosine kinase 2 transmembrane protein (ERBB2, alias Her2 or Her2/Neu) and epidermal growth factor receptor, ERBB3, or ERBB4. Binding of ligand activates a signaling cascade involving other kinases, including RAS proteins, RAF proteins, mitogen-activated protein kinase kinases (MAP2Ks or MEKs), and mitogen-activated protein kinases (MAPKs, alias extracellular signal regulated kinases). These ultimately phosphorylate downstream targets, including nuclear ER $\alpha$ and other targets, further promoting transcription. Activation of the Her2 pathway also activates the phosphoinositide-3-kinase complex (PI3K), including the catalytic subunit phosphatidylinositol-4,5-bisphosphate 3-kinase catalytic subunit $\alpha$ (PIK3CA). PI3K activates a number of downstream pathways by phosphorylation of target proteins, including AKT isoforms 1, 2, and 3. AKTs in turn activate downstream targets, including the mechanistic target of rapamycin (mTOR) complexes 1 and 2, which activate many downstream processes, including ER $\alpha$-mediated transcription. Neoplastic cells expressing Her2 may be therapeutically targeted in at the extracellular domain (by trastuzumab) or the intracellular domain (by lapitinib) and are identified by several different in vitro CDx assays making use of IHC, FISH, or CISH. Notably, different IHC antibodies may preferentially detect either the extracellular or intracellular portion of Her2. 3: DNA damage is detected by the ataxia telangiectasia mutated (ATM) protein, which activates poly(ADP-ribose) polymerase 1 (PARP-1) and recruits the breast cancer associated (BRCA) complex (including BRCA1 and BRCA2, among others). PARP inhibitors (PARPis) such as rucaparib are approved treatment in the context of ovarian cancer, when a CDx assay (based on direct sequencing of BRCA genes or mutational signature) indicates mutation or dysfunction of the BRCA complex. ATM separately recruits p53, mediating a distinct DNA-repair mechanism and antagonism of the cell-cycle. p53 is normally inhibited by mouse double minute homolog 2 (MDM2), which is itself inhibited by an investigational class of drugs called nutlins (eg, idasanutlin). 4: The cell cycle is driven by a complex periodic interaction of a number of proteins, including cyclins, cyclin dependent kinases (CDKs), CDK inhibitors (including p15, p16, and p27), checkpoint kinases (CHKs), and regulated by retinoblastoma 1 (Rb1). Palbociclib inhibits CDK4 and CDK6. The proliferative status of a tissue can be assayed using the IHC for expression of the marker of proliferation Ki-67 (MKI67). PTEN, phosphate and tensin homolog; TSC, tuberous sclerosis. 
DNA-damage detection, repair proteins, etc.), each component may carry one or more genetic variants, and any or all may be involved in carcinogenesis. Evaluation of Ki67 by IHC is believed to be an independent prognostic predictor, with greater proliferation corresponding to poorer outcomes. At very high and very low levels of expression, $\mathrm{Ki}-67$ is effectively used to stratify patients into cohorts likely to benefit from standard chemotherapy and unlikely to benefit. For those patients with intermediate expression, however, reproducibility of clinical outcomes been inconsistent. ${ }^{70-74}$ Many of the relevant confounding issues from other IHC assays pertain, including ischemic time and fixation time, but the Ki-67 antigen also demonstrates additional biological heterogeneity, with higher proliferation rates often being observed at the edge of the tumor and frequent hotspots. ${ }^{70}$ Some data suggest more consistency may be achieved by computer-assisted image analysis. ${ }^{75}$ Assessment of $\mathrm{Ki}-67$ provides another example of a pathway-centered approach to diagnostics: a comparatively simple assay evaluating a pathway or global process, rather than a specific targetable protein or genomic alteration.

\section{Immune-Checkpoint Inhibitors}

Immune-checkpoint inhibitors (ICIs) have been successfully deployed to treat a number of cancers, ${ }^{76-80}$ and they have shown promise in the treatment of breast cancer. ${ }^{81-83}$ Unlike other targeted therapies discussed above ( $E R, P R$, and Her-2 and Sequencing, Clinical Genomics, and Future Companion Diagnostics), ICIs do not act to antagonize specific molecular alterations driving cancer (as trastuzumab inhibits overexpressed Her-2); rather, ICIs relieve inhibition of the immune system by blocking the T-cell surface molecule, programed cell death 1 (PD-1, alias CD279); programed cell death ligand 1 (PDL-1, alias CD274), expressed on the surface of tumor cells; or another T-cell surface molecule, cytotoxic T-lymphocyte associated protein 4 (CTL-4, alias CD152). Relevant clinical biomarkers for ICIs differ from many cancer biomarkers, because they identify properties of the tumor and the tumor environment not directly related to cancer drivers, including expression of the target molecules or their ligands, the presence of tumor infiltrating lymphocytes (TILs), and the antigenicity of the tumor [neoantigen expression or tumor mutational burden (TMB)]. Attempts to implement and integrate these biomarkers clinically illustrate advantages and challenges for the companion diagnostic model.

Only one IHC test (PD-L1 IHC 22C3; pharmDx; Dako, Glostrup Municipality, Denmark) is currently approved by the FDA as an IVD companion diagnostic for an ICI (pembrolizumab) for use in non-small cell lung cancer ( $h t t p s: / / w w w$. fda.gov/MedicalDevices/ProductsandMedicalProcedures/ InVitroDiagnostics/ucm301431.htm, last accessed April 4, 2017). At least three other IHC assays [PD-L1 IHC 28-8 pharmDx (Dako); PD-L1 (SP142) (Ventana Medical Systems,
Inc., Oro Valley, AZ); and PD-L1 (SP263) (Ventana)] are FDA approved as complementary diagnostics for nivolumab, atezolizumab, and durvalumab, respectively. The complementary designation remains to be formally defined, but it currently confers a recommendation (rather than a requirement) for use with an associated therapy. ${ }^{84}$ Several other ICIs are approved or in development, each with a potentially different IHC platform or antibody clone associated with the target. The challenges of standardizing the technical and interpretive guidelines for IHC for ER, PR, and Her-2 are thus compounded for ICIs, with different drugs associated with different platforms, each with a different scoring algorithm. ${ }^{85,86}$ Moreover, PD-L1 can show significant expression in infiltrating immune cells, potentially confounding the interpretation of a positive IHC signal. ${ }^{86}$ Further complicating the use of these companion diagnostics is the indirect nature of ICIs; it is quickly becoming clear that additional biological information about a given patient can increase the prognostic value of anti-PD-L1 IHC.

Because ICIs act by disinhibition of the immune system, the antigenicity of the neoplastic cells relates to the efficacy of therapy. The degree to which neoplastic cells acquire and present neoantigen peptides to TILs is indirectly assessed by quantification of TMB, with a high TMB correlating with improved outcomes when patients are treated with ICIs. Although in some cases, high TMB can be inferred from other patient data (eg, BRCA status), direct assessment of TMB makes use of MPS to estimate the number of mutations per megabase. TMB varies between tumor types and between patients, and it does appear to correlate with patient response to ICIs. ${ }^{87-93}$ Many questions remain regarding the standardization and guidelines for the detection and reporting of TMB, but at least one prominent MPS reference laboratory is reporting estimates of TMB (Foundation Medicine, Cambridge MA). Irrespective of the TMB (or even the expression of the appropriate ICI target), if T cells are not present in the tumor tissue, treatment with ICIs may be less effective. ${ }^{79,87}$ The presence of TILs has itself been demonstrated to be an independent prognostic factor in breast cancer, particularly in tumors that are ER/PR/Her-2 negative, ${ }^{94-98}$ but TILs have yet to be specifically associated with response to ICIs in breast cancer. In non-small cell lung cancer, the nature of TIL subpopulations (determined by cell-surface marker expression) carry prognostic associations as well. ${ }^{99}$ As more data accumulate, the assessment of both TMB and TILs may need to be integrated into treatment algorithms for ICIs.

Targeted genetic sequencing will also likely play a role in monitoring and possibly selecting ICI therapy. As discussed above in the context of ESRI and ERBB2 resistance variants, most cancer treatments will place cancer cells under pressure to evolve, generating escape mutations over time. Loss-of-function variants leading to ICI escape have been reported in Janus kinase genes ( $J A K-1$ and $J A K-2), \beta-2$ microglobulin, and PTEN in melanoma and colon cancer. $^{100,101}$ More such variants are likely to be identified as the indications for ICI therapy expand to include other 
diagnoses, and longer-term outcomes can be assessed. It would not be inappropriate to recommend sequencing these genes in the context of ICI therapy, particularly when there is reason to suspect therapeutic resistance. Moreover, because ICIs make use of the patient's own immune system, it is quite likely that the patient's germline genomic context influences the effectiveness of treatment, although this is an area that has yet to be explored with much rigor. ${ }^{102}$

ICI therapy is a promising new tool in the armamentarium against breast cancer. As a companion diagnostic, IHC for PD-L1 maintains some of the advantages associated with other IVD companion diagnostics, particularly that it reduces the complexity of the immune system to a comparatively straightforward clinical assay. The reductive nature of the test, though, also illustrates many of the challenges in using an IVD companion diagnostic to assay a complex system.

\section{Challenges for Companion Diagnostics}

The companion diagnostic model is attractive in its simplicity; the detection of a clearly defined molecular abnormality or abnormalities indicates the use of a specific therapy, and the test and the drug are approved and regulated by a single authority (the FDA). As new targets are identified and new therapies produced, the simplicity of the model starts to pose challenges for patients, the health care system, and manufacturers (http://www.fda.gov/MedicalDevices/ NewsEvents/WorkshopsConferences/ucm436716.htm, last accessed April 4, 2017). ${ }^{81,103,104}$ When the spectrum of clinically relevant molecular or genomic changes characterizing a specific neoplasm is narrow and the number of potential therapies for any given target is low, a companion diagnostic model functions well, as with Her-2 amplification/ overexpression acting as the principle predictive biomarker for treatment by trastuzumab in breast carcinoma. However, neither biology nor industry naturally operate according to strict one-to-one relationships. Multiple genetic variants might alter response to a single therapy (eg, MDM2 amplification and TP53 variants affecting MDM2 antagonists), and multiple therapies might be indicated by a single biomarker (eg, estrogen ablation or antagonism based on ER expression). Our understanding of biology and our ability to intervene continually advance, altering the therapeutic landscape, sometimes drastically.

Indeed, as illustrated above and elsewhere in this issue, the generation of massive amounts of genomic, expression, and proteomic data regularly introduces novel biomarkers that inform and modify each other. If even a subset of these biomarkers result in targeted therapies, the number of individual assays necessary for a given patient will increase exponentially. All breast cancer patients are already assessed for ER, PR, and Her-2; depending on the clinical context, a significant proportion will have BRCAl and $B R C A 2$ testing as well (Figure 1). Increasingly, patients will go on to have expression array or genomic sequencingbased testing, particularly those patients with advanced disease. New therapies and biomarkers will continue to accumulate, and algorithms for diagnosis and treatment will necessarily become lengthier and more complex. Any individual biomarker may also be confounded by driver or resistance variants (as with Her-2, among others) which may also need to be identified to guide therapy.

This is not a trivial issue for patients, the laboratory, or clinicians. Tissue requirements, particularly from small biopsy specimens, may limit the number of independent tests that can be reasonably performed. To support multiple tests, laboratories could adopt multiple testing platforms, requiring expertise, training, capital investment, and space. Others might opt to send out some or all of their testing. Either strategy potentially increases cost and time to diagnosis or treatment for patients. Maintaining quality control for each test can be challenging as well. As described for $\mathrm{ER}, \mathrm{PR}$, and Her-2, above, a significant challenge in breast cancer has been identification and standardization of variables affecting biomarker testing. Integration of the resultant diagnostic data, arriving from different sources at different times, poses an interpretive and informatics challenge for pathologists and clinicians. Compounding the problem is the possibility that different therapeutics might target the same biomarker, but do not necessarily use the same companion diagnostic. One has only to look at the landscape of ICIs to begin to see this type of burgeoning complexity. ${ }^{105}$

For research, the introduction of multiplex, multiparametric, and high-throughput approaches has been an unequivocal boon, driving a rapid expansion in the ability to interrogate cancer genomes, transcriptomes, and proteomes to identify novel drivers and biomarkers of cancer (Figure 2). For clinical care, the increased understanding offered by the omics techniques may be something of a mixed blessing; greater insight into cancer biology brings the potential to develop an abundance of targeted therapeutics, but also a potential web of independent diagnostic tests. Despite this, as methods such as expression arrays, DNA-MPS, RNAsequencing, and mass cytometry continue to evolve from research tools to a robust diagnostic techniques, they might provide the path forward in the clinical realm. For example, MPS-based diagnostic assays (when appropriately designed) are capable of detecting thousands of different variants from thousands of different genes, all on the same assay. Importantly, a single assay may simultaneously identify different types of variant: single-nucleotide variants, insertions, deletions, splice-variants, promoter alterations, copy number variants (including loss of heterozygosity), gene fusions, and other structural rearrangements are all identifiable in the same assay. ${ }^{106}$ Moreover, such multiplex assays can also identify biological patterns in a patient specimen, including tumor heterogeneity, ${ }^{27,28} \mathrm{TMB}^{89}$ and specific mutational signatures. $^{46,55}$ If RNA-sequencing is included, either as an integrated assay or in parallel, expression data and improved detection of splice variants and novel structural variants may 
be incorporated. Patient classification into clinically relevant subtypes may be accomplished on the same assays as identification of driver mutations, resistance mutations, therapeutic modifiers, and germline risk variants. ${ }^{28,107}$ Although much more limited in current clinical adoption, proteomic approaches can also detect differential expression profiles that can elude genomic techniques, ${ }^{108}$ including posttranslational modifications ${ }^{109}$ and extracellular matrix proteins. ${ }^{110}$ Mass spectrometry can be coupled with immunohistochemical methods to permit in situ multiplexed identification at the cellular and even subcellular level. ${ }^{111}$ Whether the substrate is nucleic acid or protein, these multiplexed, multiparametric techniques maximize the identification of clinically relevant information (including many biomarkers currently assessed by IVD companion diagnostics) with the potential for reducing overall tissue requirements, standardizing quality control, and consolidating interpretation and reporting. These are all developing techniques, though, with challenges of their own because of their high technical and interpretive complexity. Importantly, they are techniques rather than specific assays and do not currently fit cleanly into the IVD companion diagnostic model.

Companion diagnostics provide unequivocal therapeutic and prognostic benefit to patients with breast cancer diagnoses. In the near-term, the generation of massive data sets from genomic studies will continue to identify new biological targets, generate new therapies, and yield novel uses for existing therapies. The more successful the strategy becomes, the more the model must adapt to accommodate patients who may harbor multiple actionable targets, requiring multiple therapies and multiple diagnostic modalities. The FDA has already intimated that another class of tests, termed complementary diagnostics, might provide an alternative in the near-future, but details and guidance in this area are limited thus far. ${ }^{84}$ Massively parallel assays, capable of identifying large numbers of biomarkers of diverse types from a single specimen, have the potential to streamline testing algorithms that might otherwise become intractably complicated. To accommodate future needs of oncology patients, the IVD companion diagnostic model will need to adapt and evolve.

\section{References}

1. Uram-Tuculescu CG, Podrumar AI: Breast tumors. Edited by Idowu MO, Dumur CI, Garrett CT. In Molecular Oncology Testing for Solid Tumors: A Pragmatic Approach. New York: Springer International Publishing, 2015. pp. 269-302

2. Lerner HJ, Band PR, Israel L, Leung BS: Phase II study of tamoxifen: report of 74 patients with stage IV breast cancer. Cancer Treat Rep 1976, 60:1431-1435

3. Fisher B, Redmond C, Brown A, Wickerham DL, Wolmark N, Allegra J, Escher G, Lippman M, Savlov E, Wittliff J: Influence of tumor estrogen and progesterone receptor levels on the response to tamoxifen and chemotherapy in primary breast cancer. J Clin Oncol $1983,1: 227-241$

4. Fisher B, Costantino J, Redmond C, Poisson R, Bowman D, Couture J, Dimitrov NV, Wolmark N, Wickerham DL, Fisher ER: A randomized clinical trial evaluating tamoxifen in the treatment of patients with node-negative breast cancer who have estrogenreceptor-positive tumors. N Engl J Med 1989, 320:479-484

5. Fisher B, Redmond C, Brown A, Wolmark N, Wittliff J, Fisher ER, Plotkin D, Bowman D, Sachs S, Wolter J, Frelick R, Desser R, LiCalzi N, Geggie P, Campbell T, Elias EG, Prager D, Koontz P, Volk H, Dimitrov N, Gardner B, Lerner H, Shibata H: Treatment of primary breast cancer with chemotherapy and tamoxifen. $\mathrm{N}$ Engl $\mathrm{J}$ Med 1981, 305:1-6

6. Fitzgibbons PL, Dillon DA, Alsabeh R, Berman MA, Hayes DF, Hicks DG, Hughes KS, Nofech-Mozes S: Template for reporting results of biomarker testing of specimens from patients with carcinoma of the breast. Arch Pathol Lab Med 2014, 138:595-601

7. Harvey JM, Clark GM, Osborne CK, Allred DC: Estrogen receptor status by immunohistochemistry is superior to the ligand-binding assay for predicting response to adjuvant endocrine therapy in breast cancer. J Clin Oncol 1999, 17:1474-1481

8. Early Breast Cancer Trialists' Collaborative Group (EBCTCG), Davies C, Godwin J, Gray R, Clarke M, Cutter D, Darby S, McGale P, Pan HC, Taylor C, Wang YC, Dowsett M, Ingle J, Peto R: Relevance of breast cancer hormone receptors and other factors to the efficacy of adjuvant tamoxifen: patient-level meta-analysis of randomised trials. Lancet 2011, 378:771-784

9. Slamon DJ, Clark GM, Wong SG, Levin WJ, Ullrich A, McGuire WL: Human breast cancer: correlation of relapse and survival with amplification of the HER-2/neu oncogene. Science 1987, 235:177-182

10. Molina MA, Codony-Servat J, Albanell J, Rojo F, Arribas J, Baselga J: Trastuzumab (herceptin), a humanized anti-Her2 receptor monoclonal antibody, inhibits basal and activated Her2 ectodomain cleavage in breast cancer cells. Cancer Res 2001, 61: 4744-4749

11. Albanell J, Baselga J: Trastuzumab, a humanized anti-HER2 monoclonal antibody, for the treatment of breast cancer. Drugs Today (Barc) 1999, 35:931-946

12. Allison KH: Molecular testing in breast cancer. Edited by Coleman WB, Tsongalis GJ. In Diagnostic Molecular Pathology: A Guide to Applied Molecular Testing. Amsterdam, the Netherlands: Elsevier Science, 2017. pp. 257-269

13. Arber DA: Effect of prolonged formalin fixation on the immunohistochemical reactivity of breast markers. Appl Immunohistochem Mol Morphol 2002, 10:183-186

14. Oyama T, Ishikawa Y, Hayashi M, Arihiro K, Horiguchi J: The effects of fixation, processing and evaluation criteria on immunohistochemical detection of hormone receptors in breast cancer. Breast Cancer 2007, 14:182-188

15. Yildiz-Aktas IZ, Dabbs DJ, Bhargava R: The effect of cold ischemic time on the immunohistochemical evaluation of estrogen receptor, progesterone receptor, and HER2 expression in invasive breast carcinoma. Mod Pathol 2012, 25:1098-1105

16. Neumeister VM, Anagnostou V, Siddiqui S, England AM, Zarrella ER, Vassilakopoulou M, Parisi F, Kluger Y, Hicks DG, Rimm DL: Quantitative assessment of effect of preanalytic cold ischemic time on protein expression in breast cancer tissues. J Natl Cancer Inst 2012, 104:1815-1824

17. Apple S, Pucci R, Lowe AC, Shintaku I, Shapourifar-Tehrani S, Moatamed N: The effect of delay in fixation, different fixatives, and duration of fixation in estrogen and progesterone receptor results in breast carcinoma. Am J Clin Pathol 2011, 135:592-598

18. Skliris GP, Parkes AT, Limer JL, Burdall SE, Carder PJ, Speirs V: Evaluation of seven oestrogen receptor beta antibodies for immunohistochemistry, western blotting, and flow cytometry in human breast tissue. J Pathol 2002, 197:155-162

19. McCarty KS Jr, Miller LS, Cox EB, Konrath J, McCarty KS Sr: Estrogen receptor analyses. Correlation of biochemical and immunohistochemical methods using monoclonal antireceptor antibodies. Arch Pathol Lab Med 1985, 109:716-721 
20. Fitzgibbons PL, Murphy DA, Hammond ME, Allred DC, Valenstein PN: Recommendations for validating estrogen and progesterone receptor immunohistochemistry assays. Arch Pathol Lab Med 2010, 134:930-935

21. Hammond ME, Hayes DF, Dowsett M, Allred DC, Hagerty KL, Badve S, Fitzgibbons PL, Francis G, Goldstein NS, Hayes M, Hicks DG, Lester S, Love R, Mangu PB, McShane L, Miller K, Osborne CK, Paik S, Perlmutter J, Rhodes A, Sasano H, Schwartz JN, Sweep FC, Taube S, Torlakovic EE, Valenstein P, Viale G, Visscher D, Wheeler T, Williams RB, Wittliff JL, Wolff AC; American Society of Clinical Oncology; College of American Pathologists: American Society of Clinical Oncology/College of American Pathologists guideline recommendations for immunohistochemical testing of estrogen and progesterone receptors in breast cancer (unabridged version). Arch Pathol Lab Med 2010, 134: e48-e72

22. Cornejo KM, Kandil D, Khan A, Cosar EF: Theranostic and molecular classification of breast cancer. Arch Pathol Lab Med 2014, $138: 44-56$

23. Willmore-Payne C, Metzger K, Layfield LJ: Effects of fixative and fixation protocols on assessment of Her-2/neu oncogene amplification status by fluorescence in situ hybridization. Appl Immunohistochem Mol Morphol 2007, 15:84-87

24. Wolff AC, Hammond ME, Hicks DG, Dowsett M, McShane LM, Allison KH, Allred DC, Bartlett JM, Bilous M, Fitzgibbons P, Hanna W, Jenkins RB, Mangu PB, Paik S, Perez EA, Press MF, Spears PA, Vance GH, Viale G, Hayes DF; American Society of Clinical Oncology; College of American Pathologists: Recommendations for human epidermal growth factor receptor 2 testing in breast cancer: American Society of Clinical Oncology/College of American Pathologists clinical practice guideline update. Arch Pathol Lab Med 2014, 138:241-256

25. Carvajal-Hausdorf DE, Schalper KA, Pusztai L, Psyrri A, Kalogeras KT, Kotoula V, Fountzilas G, Rimm DL: Measurement of domain-specific HER2 (ERBB2) expression may classify benefit from trastuzumab in breast cancer. J Natl Cancer Inst 2015, 107: djv136

26. Hui L, Geiersbach KB, Downs-Kelly E, Gulbahce HE: RAI1 alternate probe identifies additional breast cancer cases as amplified following equivocal HER2 fluorescence in situ hybridization testing: experience from a National Reference Laboratory. Arch Pathol Lab Med 2017, 141:274-278

27. Shah SP, Roth A, Goya R, Oloumi A, Ha G, Zhao Y, et al: The clonal and mutational evolution spectrum of primary triple-negative breast cancers. Nature 2012, 486:395-399

28. Pereira B, Chin SF, Rueda OM, Vollan HK, Provenzano E, Bardwell HA, Pugh M, Jones L, Russell R, Sammut SJ, Tsui DW, Liu B, Dawson SJ, Abraham J, Northen H, Peden JF, Mukherjee A, Turashvili G, Green AR, McKinney S, Oloumi A, Shah S, Rosenfeld N, Murphy L, Bentley DR, Ellis IO, Purushotham A, Pinder SE, Borresen-Dale AL, Earl HM, Pharoah PD, Ross MT, Aparicio S, Caldas C: The somatic mutation profiles of 2,433 breast cancers refines their genomic and transcriptomic landscapes. Nat Commun 2016, 7:11479

29. Seol H, Lee HJ, Choi Y, Lee HE, Kim YJ, Kim JH, Kang E, Kim SW, Park SY: Intratumoral heterogeneity of HER2 gene amplification in breast cancer: its clinicopathological significance. Mod Pathol 2012, 25:938-948

30. Robinson DR, Wu YM, Vats P, Su F, Lonigro RJ, Cao X, KalyanaSundaram S, Wang R, Ning Y, Hodges L, Gursky A, Siddiqui J, Tomlins SA, Roychowdhury S, Pienta KJ, Kim SY, Roberts JS, Rae JM, Van Poznak CH, Hayes DF, Chugh R, Kunju LP, Talpaz M, Schott AF, Chinnaiyan AM: Activating ESR1 mutations in hormoneresistant metastatic breast cancer. Nat Genet 2013, 45:1446-1451

31. Toy W, Shen Y, Won H, Green B, Sakr RA, Will M, Li Z, Gala K, Fanning S, King TA, Hudis C, Chen D, Taran T, Hortobagyi G, Greene G, Berger M, Baselga J, Chandarlapaty S: ESR1 ligand-binding domain mutations in hormone-resistant breast cancer. Nat Genet 2013 45:1439-1445

32. Merenbakh-Lamin K, Ben-Baruch N, Yeheskel A, Dvir A, Soussan-Gutman L, Jeselsohn R, Yelensky R, Brown M, Miller VA, Sarid D, Rizel S, Klein B, Rubinek T, Wolf I: D538G mutation in estrogen receptor-alpha: a novel mechanism for acquired endocrine resistance in breast cancer. Cancer Res 2013, 73:6856-6864

33. Jeselsohn R, Yelensky R, Buchwalter G, Frampton G, MericBernstam F, Gonzalez-Angulo AM, Ferrer-Lozano J, PerezFidalgo JA, Cristofanilli M, Gomez H, Arteaga CL, Giltnane J, Balko JM, Cronin MT, Jarosz M, Sun J, Hawryluk M, Lipson D, Otto G, Ross JS, Dvir A, Soussan-Gutman L, Wolf I, Rubinek T, Gilmore L, Schnitt S, Come SE, Pusztai L, Stephens P, Brown M, Miller VA: Emergence of constitutively active estrogen receptoralpha mutations in pretreated advanced estrogen receptor-positive breast cancer. Clin Cancer Res 2014, 20:1757-1767

34. Rexer BN, Arteaga CL: Intrinsic and acquired resistance to HER2targeted therapies in HER2 gene-amplified breast cancer: mechanisms and clinical implications. Crit Rev Oncog 2012, 17:1-16

35. Groenendijk FH, Zwart W, Floore A, Akbari S, Bernards R: Estrogen receptor splice variants as a potential source of false-positive estrogen receptor status in breast cancer diagnostics. Breast Cancer Res Treat 2013, 140:475-484

36. Bose R, Kavuri SM, Searleman AC, Shen W, Shen D, Koboldt DC, Monsey J, Goel N, Aronson AB, Li S, Ma CX, Ding L, Mardis ER, Ellis MJ: Activating HER2 mutations in HER2 gene amplification negative breast cancer. Cancer Discov 2013, 3:224-237

37. Ross JS, Wang $\mathrm{K}$, Sheehan $\mathrm{CE}$, Boguniewicz AB, Otto G, Downing SR, Sun J, He J, Curran JA, Ali S, Yelensky R, Lipson D, Palmer G, Miller VA, Stephens PJ: Relapsed classic E-cadherin (CDH1)-mutated invasive lobular breast cancer shows a high frequency of HER2 (ERBB2) gene mutations. Clin Cancer Res 2013, 19:2668-2676

38. Greulich H, Kaplan B, Mertins P, Chen TH, Tanaka KE, Yun CH, Zhang X, Lee SH, Cho J, Ambrogio L, Liao R, Imielinski M, Banerji S, Berger AH, Lawrence MS, Zhang J, Pho NH, Walker SR, Winckler W, Getz G, Frank D, Hahn WC, Eck MJ, Mani DR, Jaffe JD, Carr SA, Wong KK, Meyerson M: Functional analysis of receptor tyrosine kinase mutations in lung cancer identifies oncogenic extracellular domain mutations of ERBB2. Proc Natl Acad Sci U S A 2012, 109:14476-14481

39. Ciriello G, Gatza ML, Beck AH, Wilkerson MD, Rhie SK, Pastore A, Zhang H, McLellan M, Yau C, Kandoth C, Bowlby R, Shen H, Hayat S, Fieldhouse R, Lester SC, Tse GM, Factor RE, Collins LC, Allison KH, Chen YY, Jensen K, Johnson NB, Oesterreich S, Mills GB, Cherniack AD, Robertson G, Benz C, Sander C, Laird PW, Hoadley KA, King TA; TCGA Research Network, Perou CM: Comprehensive molecular portraits of invasive lobular breast cancer. Cell 2015, 163:506-519

40. Banerji S, Cibulskis K, Rangel-Escareno C, Brown KK, Carter SL, Frederick AM, et al: Sequence analysis of mutations and translocations across breast cancer subtypes. Nature 2012, 486:405-409

41. Stephens PJ, Tarpey PS, Davies H, Van Loo P, Greenman C, Wedge DC, et al: The landscape of cancer genes and mutational processes in breast cancer. Nature 2012, 486:400-404

42. Cancer Genome Atlas Network: Comprehensive molecular portraits of human breast tumours. Nature 2012, 490:61-70

43. Gao J, Aksoy BA, Dogrusoz U, Dresdner G, Gross B, Sumer SO, Sun Y, Jacobsen A, Sinha R, Larsson E, Cerami E, Sander C, Schultz N: Integrative analysis of complex cancer genomics and clinical profiles using the cBioPortal. Sci Signal 2013, 6:p11

44. Cerami E, Gao J, Dogrusoz U, Gross BE, Sumer SO, Aksoy BA, Jacobsen A, Byrne CJ, Heuer ML, Larsson E, Antipin Y, Reva B, Goldberg AP, Sander C, Schultz N: The cBio cancer genomics portal: an open platform for exploring multidimensional cancer genomics data. Cancer Discov 2012, 2:401-404 
45. Weisman PS, Ng CK, Brogi E, Eisenberg RE, Won $\mathrm{HH}$, Piscuoglio S, De Filippo MR, Ioris R, Akram M, Norton L, Weigelt B, Berger MF, Reis-Filho JS, Wen HY: Genetic alterations of triple negative breast cancer by targeted next-generation sequencing and correlation with tumor morphology. Mod Pathol 2016, 29:476-488

46. Nik-Zainal S, Davies H, Staaf J, Ramakrishna M, Glodzik D, Zou X, et al: Landscape of somatic mutations in 560 breast cancer wholegenome sequences. Nature 2016, 534:47-54

47. Finkelman BS, Rubinstein WS, Friedman S, Friebel TM, Dubitsky S, Schonberger NS, Shoretz R, Singer CF, Blum JL, Tung N, Olopade OI, Weitzel JN, Lynch HT, Snyder C, Garber JE, Schildkraut J, Daly MB, Isaacs C, Pichert G, Neuhausen SL, Couch FJ, van't Veer L, Eeles R, Bancroft E, Evans DG, Ganz PA, Tomlinson GE, Narod SA, Matloff E, Domchek S, Rebbeck TR: Breast and ovarian cancer risk and risk reduction in Jewish BRCA1/2 mutation carriers. J Clin Oncol 2012, 30:1321-1328

48. Koczkowska M, Zuk M, Gorczynski A, Ratajska M, Lewandowska M, Biernat W, Limon J, Wasag B: Detection of somatic BRCA1/2 mutations in ovarian cancer - next-generation sequencing analysis of 100 cases. Cancer Med 2016, 5:1640-1646

49. Del Conte G, Sessa C, von Moos R, Vigano L, Digena T, Locatelli A, Gallerani E, Fasolo A, Tessari A, Cathomas R, Gianni L: Phase I study of olaparib in combination with liposomal doxorubicin in patients with advanced solid tumours. Br J Cancer 2014, 111:651-659

50. Balmana J, Tung NM, Isakoff SJ, Grana B, Ryan PD, Saura C, Lowe ES, Frewer P, Winer E, Baselga J, Garber JE: Phase I trial of olaparib in combination with cisplatin for the treatment of patients with advanced breast, ovarian and other solid tumors. Ann Oncol 2014, 25:1656-1663

51. Fong PC, Boss DS, Yap TA, Tutt A, Wu P, Mergui-Roelvink M, Mortimer P, Swaisland H, Lau A, O'Connor MJ, Ashworth A, Carmichael J, Kaye SB, Schellens JH, de Bono JS: Inhibition of poly(ADP-ribose) polymerase in tumors from BRCA mutation carriers. N Engl J Med 2009, 361:123-134

52. Tutt A, Robson M, Garber JE, Domchek SM, Audeh MW, Weitzel JN, Friedlander M, Arun B, Loman N, Schmutzler RK, Wardley A, Mitchell G, Earl H, Wickens M, Carmichael J: Oral poly(ADP-ribose) polymerase inhibitor olaparib in patients with BRCA1 or BRCA2 mutations and advanced breast cancer: a proof-ofconcept trial. Lancet 2010, 376:235-244

53. Benafif S, Hall M: An update on PARP inhibitors for the treatment of cancer. Onco Targets Ther 2015, 8:519-528

54. Naipal KA, Verkaik NS, Ameziane N, van Deurzen CH, Ter Brugge P, Meijers M, Sieuwerts AM, Martens JW, O’Connor MJ, Vrieling H, Hoeijmakers JH, Jonkers J, Kanaar R, de Winter JP, Vreeswijk MP, Jager A, van Gent DC: Functional ex vivo assay to select homologous recombination-deficient breast tumors for PARP inhibitor treatment. Clin Cancer Res 2014, 20:4816-4826

55. Alexandrov LB, Nik-Zainal S, Wedge DC, Aparicio SA, Behjati S, Biankin AV, et al: Signatures of mutational processes in human cancer. Nature 2013, 500:415-421

56. Mayer IA, Abramson VG, Formisano L, Balko JM, Estrada MV, Sanders ME, Juric D, Solit D, Berger MF, Won HH, Li Y, Cantley LC, Winer E, Arteaga CL: A phase Ib study of alpelisib (BYL719), a PI3Kalpha-specific inhibitor, with letrozole in ER+/HER2- metastatic breast cancer. Clin Cancer Res 2017, 23: 26-34

57. Sanchez CG, Ma CX, Crowder RJ, Guintoli T, Phommaly C, Gao F, Lin L, Ellis MJ: Preclinical modeling of combined phosphatidylinositol-3-kinase inhibition with endocrine therapy for estrogen receptorpositive breast cancer. Breast Cancer Res 2011, 13:R21

58. Rodon J, Brana I, Siu LL, De Jonge MJ, Homji N, Mills D, Di Tomaso E, Sarr C, Trandafir L, Massacesi C, Eskens F, Bendell JC: Phase I dose-escalation and -expansion study of buparlisib (BKM120), an oral pan-Class I PI3K inhibitor, in patients with advanced solid tumors. Invest New Drugs 2014, 32:670-681
59. Loibl S, von Minckwitz G, Schneeweiss A, Paepke S, Lehmann A, Rezai M, Zahm DM, Sinn P, Khandan F, Eidtmann H, Dohnal K, Heinrichs C, Huober J, Pfitzner B, Fasching PA, Andre F, Lindner JL, Sotiriou C, Dykgers A, Guo S, Gade S, Nekljudova V, Loi S, Untch M, Denkert C: PIK3CA mutations are associated with lower rates of pathologic complete response to anti-human epidermal growth factor receptor 2 (her2) therapy in primary HER2overexpressing breast cancer. J Clin Oncol 2014, 32:3212-3220

60. Brachova P, Thiel KW, Leslie KK: The consequence of oncomorphic TP53 mutations in ovarian cancer. Int J Mol Sci 2013, 14: 19257-19275

61. Vassilev LT, Vu BT, Graves B, Carvajal D, Podlaski F, Filipovic Z, Kong N, Kammlott U, Lukacs C, Klein C, Fotouhi N, Liu EA: In vivo activation of the p53 pathway by small-molecule antagonists of MDM2. Science 2004, 303:844-848

62. Shangary S, Qin D, McEachern D, Liu M, Miller RS, Qiu S, Nikolovska-Coleska Z, Ding K, Wang G, Chen J, Bernard D, Zhang J, Lu Y, Gu Q, Shah RB, Pienta KJ, Ling X, Kang S, Guo M, Sun Y, Yang D, Wang S: Temporal activation of p53 by a specific MDM2 inhibitor is selectively toxic to tumors and leads to complete tumor growth inhibition. Proc Natl Acad Sci U S A 2008, 105: 3933-3938

63. Nag S, Zhang X, Srivenugopal KS, Wang MH, Wang W, Zhang R: Targeting MDM2-p53 interaction for cancer therapy: are we there yet? Curr Med Chem 2014, 21:553-574

64. Shangary S, Wang S: Targeting the MDM2-p53 interaction for cancer therapy. Clin Cancer Res 2008, 14:5318-5324

65. Finn RS, Martin M, Rugo HS, Jones S, Im SA, Gelmon K, Harbeck N, Lipatov ON, Walshe JM, Moulder S, Gauthier E, Lu DR, Randolph S, Dieras V, Slamon DJ: Palbociclib and letrozole in advanced breast cancer. N Engl J Med 2016, 375:1925-1936

66. Finn RS, Crown JP, Ettl J, Schmidt M, Bondarenko IM, Lang I, Pinter T, Boer K, Patel R, Randolph S, Kim ST, Huang X, Schnell P, Nadanaciva S, Bartlett CH, Slamon DJ: Efficacy and safety of palbociclib in combination with letrozole as first-line treatment of ER-positive, HER2-negative, advanced breast cancer: expanded analyses of subgroups from the randomized pivotal trial PALOMA1/TRIO-18. Breast Cancer Res 2016, 18:67

67. Katoh M: FGFR inhibitors: effects on cancer cells, tumor microenvironment and whole-body homeostasis (Review). Int J Mol Med 2016, 38:3-15

68. Yardley DA, Ismail-Khan RR, Melichar B, Lichinitser M, Munster PN, Klein PM, Cruickshank S, Miller KD, Lee MJ, Trepel JB: Randomized phase II, double-blind, placebo-controlled study of exemestane with or without entinostat in postmenopausal women with locally recurrent or metastatic estrogen receptor-positive breast cancer progressing on treatment with a nonsteroidal aromatase inhibitor. J Clin Oncol 2013, 31:2128-2135

69. Sparano JA, Gray RJ, Makower DF, Pritchard KI, Albain KS, Hayes DF, Geyer CE Jr, Dees EC, Perez EA, Olson JA Jr, Zujewski J, Lively T, Badve SS, Saphner TJ, Wagner LI, Whelan TJ, Ellis MJ, Paik S, Wood WC, Ravdin P, Keane MM, Gomez Moreno HL, Reddy PS, Goggins TF, Mayer IA, Brufsky AM, Toppmeyer DL, Kaklamani VG, Atkins JN, Berenberg JL, Sledge GW: Prospective validation of a 21-gene expression assay in breast cancer. $\mathrm{N}$ Engl $\mathrm{J}$ Med 2015, 373:2005-2014

70. Dowsett M, Nielsen TO, A'Hern R, Bartlett J, Coombes RC, Cuzick J, Ellis M, Henry NL, Hugh JC, Lively T, McShane L, Paik S, Penault-Llorca F, Prudkin L, Regan M, Salter J, Sotiriou C, Smith IE, Viale G, Zujewski JA, Hayes DF; International Ki-67 in Breast Cancer Working Group: Assessment of Ki67 in breast cancer: recommendations from the International Ki67 in Breast Cancer Working Group. J Natl Cancer Inst 2011, 103:1656-1664

71. Urruticoechea A, Smith IE, Dowsett M: Proliferation marker Ki-67 in early breast cancer. J Clin Oncol 2005, 23:7212-7220

72. Dowsett M, Smith IE, Ebbs SR, Dixon JM, Skene A, A'Hern R, Salter J, Detre S, Hills M, Walsh G; IMPACT Trialists Group: 
Prognostic value of Ki67 expression after short-term presurgical endocrine therapy for primary breast cancer. J Natl Cancer Inst 2007, 99:167-170

73. Filipits M, Rudas M, Jakesz R, Dubsky P, Fitzal F, Singer CF, Dietze O, Greil R, Jelen A, Sevelda P, Freibauer C, Muller V, Janicke F, Schmidt M, Kolbl H, Rody A, Kaufmann M, Schroth W, Brauch H, Schwab M, Fritz P, Weber KE, Feder IS, Hennig G, Kronenwett R, Gehrmann M, Gnant M; EP Investigators: A new molecular predictor of distant recurrence in ER-positive, HER2-negative breast cancer adds independent information to conventional clinical risk factors. Clin Cancer Res 2011, 17:6012-6020

74. Ellis MJ, Tao Y, Luo J, A'Hern R, Evans DB, Bhatnagar AS, Chaudri Ross HA, von Kameke A, Miller WR, Smith I, Eiermann W, Dowsett M: Outcome prediction for estrogen receptor-positive breast cancer based on postneoadjuvant endocrine therapy tumor characteristics. J Natl Cancer Inst 2008, 100:1380-1388

75. Stalhammar G, Fuentes Martinez N, Lippert M, Tobin NP, Molholm I, Kis L, Rosin G, Rantalainen M, Pedersen L, Bergh J, Grunkin M, Hartman J: Digital image analysis outperforms manual biomarker assessment in breast cancer. Mod Pathol 2016, 29:318-329

76. Topalian SL, Hodi FS, Brahmer JR, Gettinger SN, Smith DC, McDermott DF, Powderly JD, Carvajal RD, Sosman JA, Atkins MB, Leming PD, Spigel DR, Antonia SJ, Horn L, Drake CG, Pardoll DM, Chen L, Sharfman WH, Anders RA, Taube JM, McMiller TL, Xu H, Korman AJ, Jure-Kunkel M, Agrawal S, McDonald D, Kollia GD, Gupta A, Wigginton JM, Sznol M: Safety, activity, and immune correlates of anti-PD-1 antibody in cancer. N Engl J Med 2012, 366: $2443-2454$

77. Herbst RS, Soria JC, Kowanetz M, Fine GD, Hamid O, Gordon MS, Sosman JA, McDermott DF, Powderly JD, Gettinger SN, Kohrt HE, Horn L, Lawrence DP, Rost S, Leabman M, Xiao Y, Mokatrin A, Koeppen H, Hegde PS, Mellman I, Chen DS, Hodi FS: Predictive correlates of response to the anti-PD-L1 antibody MPDL3280A in cancer patients. Nature 2014, 515:563-567

78. Garon EB, Rizvi NA, Hui R, Leighl N, Balmanoukian AS, Eder JP, Patnaik A, Aggarwal C, Gubens M, Horn L, Carcereny E, Ahn MJ, Felip E, Lee JS, Hellmann MD, Hamid O, Goldman JW, Soria JC, Dolled-Filhart M, Rutledge RZ, Zhang J, Lunceford JK, Rangwala R, Lubiniecki GM, Roach C, Emancipator K, Gandhi L; KEYNOTE001 Investigators: Pembrolizumab for the treatment of non-small-cell lung cancer. N Engl J Med 2015, 372:2018-2028

79. Tumeh PC, Harview CL, Yearley JH, Shintaku IP, Taylor EJ, Robert L, Chmielowski B, Spasic M, Henry G, Ciobanu V, West AN, Carmona M, Kivork C, Seja E, Cherry G, Gutierrez AJ, Grogan TR, Mateus C, Tomasic G, Glaspy JA, Emerson RO, Robins H, Pierce RH, Elashoff DA, Robert C, Ribas A: PD-1 blockade induces responses by inhibiting adaptive immune resistance. Nature 2014, 515:568-571

80. Weber JS, D’Angelo SP, Minor D, Hodi FS, Gutzmer R, Neyns B, Hoeller C, Khushalani NI, Miller WH Jr, Lao CD, Linette GP, Thomas L, Lorigan P, Grossmann KF, Hassel JC, Maio M, Sznol M, Ascierto PA, Mohr P, Chmielowski B, Bryce A, Svane IM, Grob JJ, Krackhardt AM, Horak C, Lambert A, Yang AS, Larkin J: Nivolumab versus chemotherapy in patients with advanced melanoma who progressed after anti-CTLA-4 treatment (CheckMate 037): a randomised, controlled, open-label, phase 3 trial. Lancet Oncol 2015, 16: 375-384

81. Dracopoli NC, Boguski MS: The evolution of oncology companion diagnostics from signal transduction to immuno-oncology. Trends Pharmacol Sci 2017, 38:41-54

82. Migali C, Milano M, Trapani D, Criscitiello C, Esposito A, Locatelli M, Minchella I, Curigliano G: Strategies to modulate the immune system in breast cancer: checkpoint inhibitors and beyond. Ther Adv Med Oncol 2016, 8:360-374

83. McArthur HL: Checkpoint inhibitors in breast cancer: hype or promise? Clin Adv Hematol Oncol 2016, 14:392-395
84. Milne CP, Bryan C, Garafalo S, McKiernan M: Complementary versus companion diagnostics: apples and oranges? Biomark Med 2015, 9:25-34

85. Kerr KM, Hirsch FR: Programmed death ligand-1 immunohistochemistry: friend or foe? Arch Pathol Lab Med 2016, 140:326-331

86. Hirsch FR, McElhinny A, Stanforth D, Ranger-Moore J, Jansson M, Kulangara K, Richardson W, Towne P, Hanks D, Vennapusa B, Mistry A, Kalamegham R, Averbuch S, Novotny J, Rubin E, Emancipator K, McCaffery I, Williams JA, Walker J, Longshore J, Tsao MS, Kerr KM: PD-L1 immunohistochemistry assays for lung cancer: results from phase 1 of the blueprint PD-L1 IHC assay comparison project. J Thorac Oncol 2017, 12:208-222

87. Le DT, Uram JN, Wang H, Bartlett BR, Kemberling H, Eyring AD, Skora AD, Luber BS, Azad NS, Laheru D, Biedrzycki B, Donehower RC, Zaheer A, Fisher GA, Crocenzi TS, Lee JJ, Duffy SM, Goldberg RM, de la Chapelle A, Koshiji M, Bhaijee F, Huebner T, Hruban RH, Wood LD, Cuka N, Pardoll DM, Papadopoulos N, Kinzler KW, Zhou S, Cornish TC, Taube JM, Anders RA, Eshleman JR, Vogelstein B, Diaz LA Jr: PD-1 blockade in tumors with mismatch-repair deficiency. N Engl J Med 2015, 372: 2509-2520

88. Rizvi NA, Hellmann MD, Snyder A, Kvistborg P, Makarov V, Havel JJ, Lee W, Yuan J, Wong P, Ho TS, Miller ML, Rekhtman N, Moreira AL, Ibrahim F, Bruggeman C, Gasmi B, Zappasodi R, Maeda Y, Sander C, Garon EB, Merghoub T, Wolchok JD, Schumacher TN, Chan TA: Cancer immunology. Mutational landscape determines sensitivity to PD-1 blockade in non-small cell lung cancer. Science 2015, 348:124-128

89. Johnson DB, Frampton GM, Rioth MJ, Yusko E, Xu Y, Guo X, Ennis RC, Fabrizio D, Chalmers ZR, Greenbowe J, Ali SM, Balasubramanian S, Sun JX, He Y, Frederick DT, Puzanov I, Balko JM, Cates JM, Ross JS, Sanders C, Robins H, Shyr Y, Miller VA, Stephens PJ, Sullivan RJ, Sosman JA, Lovly CM: Targeted next generation sequencing identifies markers of response to PD-1 blockade. Cancer Immunol Res 2016, 4:959-967

90. Schumacher TN, Schreiber RD: Neoantigens in cancer immunotherapy. Science 2015, 348:69-74

91. Van Allen EM, Miao D, Schilling B, Shukla SA, Blank C, Zimmer L, Sucker A, Hillen U, Geukes Foppen MH, Goldinger SM, Utikal J, Hassel JC, Weide B, Kaehler KC, Loquai C, Mohr P, Gutzmer R, Dummer R, Gabriel S, Wu CJ, Schadendorf D, Garraway LA: Genomic correlates of response to CTLA-4 blockade in metastatic melanoma. Science 2015, 350:207-211

92. Hugo W, Zaretsky JM, Sun L, Song C, Moreno BH, Hu-Lieskovan S, Berent-Maoz B, Pang J, Chmielowski B, Cherry G, Seja E, Lomeli S, Kong X, Kelley MC, Sosman JA, Johnson DB, Ribas A, Lo RS: Genomic and transcriptomic features of response to anti-PD-1 therapy in metastatic melanoma. Cell 2016, 165:35-44

93. Snyder A, Makarov V, Merghoub T, Yuan J, Zaretsky JM, Desrichard A, Walsh LA, Postow MA, Wong P, Ho TS, Hollmann TJ, Bruggeman C, Kannan K, Li Y, Elipenahli C, Liu C, Harbison CT, Wang L, Ribas A, Wolchok JD, Chan TA: Genetic basis for clinical response to CTLA-4 blockade in melanoma. N Engl J Med 2014, 371:2189-2199

94. Loi S, Michiels S, Salgado R, Sirtaine N, Jose V, Fumagalli D, Kellokumpu-Lehtinen PL, Bono P, Kataja V, Desmedt C, Piccart MJ, Loibl S, Denkert C, Smyth MJ, Joensuu H, Sotiriou C: Tumor infiltrating lymphocytes are prognostic in triple negative breast cancer and predictive for trastuzumab benefit in early breast cancer: results from the FinHER trial. Ann Oncol 2014, 25:1544-1550

95. Adams S, Gray RJ, Demaria S, Goldstein L, Perez EA, Shulman LN, Martino S, Wang M, Jones VE, Saphner TJ, Wolff AC, Wood WC, Davidson NE, Sledge GW, Sparano JA, Badve SS: Prognostic value of tumor-infiltrating lymphocytes in triple-negative breast cancers from two phase III randomized adjuvant breast cancer trials: ECOG 2197 and ECOG 1199. J Clin Oncol 2014, 32:2959-2966 
96. Denkert C, Loibl S, Noske A, Roller M, Muller BM, Komor M, Budczies J, Darb-Esfahani S, Kronenwett R, Hanusch C, von Torne C, Weichert W, Engels K, Solbach C, Schrader I, Dietel M, von Minckwitz G: Tumor-associated lymphocytes as an independent predictor of response to neoadjuvant chemotherapy in breast cancer. $\mathrm{J}$ Clin Oncol 2010, 28:105-113

97. Denkert C, von Minckwitz G, Brase JC, Sinn BV, Gade S, Kronenwett R, Pfitzner BM, Salat C, Loi S, Schmitt WD, Schem C, Fisch K, Darb-Esfahani S, Mehta K, Sotiriou C, Wienert S, Klare P, Andre F, Klauschen F, Blohmer JU, Krappmann K, Schmidt M, Tesch H, Kummel S, Sinn P, Jackisch C, Dietel M, Reimer T, Untch M, Loibl S: Tumor-infiltrating lymphocytes and response to neoadjuvant chemotherapy with or without carboplatin in human epidermal growth factor receptor 2-positive and triple-negative primary breast cancers. J Clin Oncol 2015, 33:983-991

98. Wimberly H, Brown JR, Schalper K, Haack H, Silver MR, Nixon C, Bossuyt V, Pusztai L, Lannin DR, Rimm DL: PD-L1 expression correlates with tumor-infiltrating lymphocytes and response to neoadjuvant chemotherapy in breast cancer. Cancer Immunol Res 2015, 3:326-332

99. Schalper KA, Brown J, Carvajal-Hausdorf D, McLaughlin J, Velcheti V, Syrigos KN, Herbst RS, Rimm DL: Objective measurement and clinical significance of TILs in non-small cell lung cancer. $\mathrm{J}$ Natl Cancer Inst 2015, 107:dju435

100. Zaretsky JM, Garcia-Diaz A, Shin DS, Escuin-Ordinas H, Hugo W, Hu-Lieskovan S, Torrejon DY, Abril-Rodriguez G, Sandoval S, Barthly L, Saco J, Homet Moreno B, Mezzadra R, Chmielowski B, Ruchalski K, Shintaku IP, Sanchez PJ, Puig-Saus C, Cherry G, Seja E, Kong X, Pang J, Berent-Maoz B, Comin-Anduix B, Graeber TG, Tumeh PC, Schumacher TN, Lo RS, Ribas A: Mutations associated with acquired resistance to PD-1 blockade in melanoma. N Engl J Med 2016, 375:819-829

101. Peng W, Chen JQ, Liu C, Malu S, Creasy C, Tetzlaff MT, et al: Loss of PTEN promotes resistance to $\mathrm{T}$ cell-mediated immunotherapy. Cancer Discov 2016, 6:202-216
102. Spira A, Disis ML, Schiller JT, Vilar E, Rebbeck TR, Bejar R, Ideker T, Arts J, Yurgelun MB, Mesirov JP, Rao A, Garber J, Jaffee EM, Lippman SM: Leveraging premalignant biology for immune-based cancer prevention. Proc Natl Acad Sci U S A 2016, 113:10750-10758

103. Agarwal A, Ressler D, Snyder G: The current and future state of companion diagnostics. Pharmgenomics Pers Med 2015, 8:99-110

104. Hayes DF, Allen J, Compton C, Gustavsen G, Leonard DG, McCormack R, Newcomer L, Pothier K, Ransohoff D, Schilsky RL, Sigal E, Taube SE, Tunis SR: Breaking a vicious cycle. Sci Transl Med 2013, 5:196cm6

105. Jorgensen JT: Companion diagnostic assays for PD-1/PD-L1 checkpoint inhibitors in NSCLC. Expert Rev Mol Diagn 2016, 16:131-133

106. Tattini L, D'Aurizio R, Magi A: Detection of genomic structural variants from next-generation sequencing data. Front Bioeng Biotechnol 2015, 3:92

107. Rantalainen M, Klevebring D, Lindberg J, Ivansson E, Rosin G, Kis L, Celebioglu F, Fredriksson I, Czene K, Frisell J, Hartman J, Bergh J, Gronberg H: Sequencing-based breast cancer diagnostics as an alternative to routine biomarkers. Sci Rep 2016, 6:38037

108. Tyanova S, Albrechtsen R, Kronqvist P, Cox J, Mann M, Geiger T: Proteomic maps of breast cancer subtypes. Nat Commun 2016, 7: 10259

109. Ulirsch J, Fan C, Knafl G, Wu MJ, Coleman B, Perou CM, SwiftScanlan T: Vimentin DNA methylation predicts survival in breast cancer. Breast Cancer Res Treat 2013, 137:383-396

110. Srinivas P, Kollapalli SP, Thomas A, Mortha KK, Banerjee SD Bioactive hyaluronan fragment (hexasaccharide) detects specific hexa-binding proteins in human breast and stomach cancer: possible role in tumorogenesis. Indian J Biochem Biophys 2012, 49:228-235

111. Giesen C, Wang HA, Schapiro D, Zivanovic N, Jacobs A, Hattendorf B, Schuffler PJ, Grolimund D, Buhmann JM, Brandt S, Varga Z, Wild PJ, Gunther D, Bodenmiller B: Highly multiplexed imaging of tumor tissues with subcellular resolution by mass cytometry. Nat Methods 2014, 11:417-422 